\title{
ZÁZNAMY SEVEROKOREJSKÝCH JADERNÝCH EXPLOZÍ NA SEISMICKÉ STANICI VRAC
}

\author{
Registrations of the North Korean nuclear explosions on the seismic station VRAC \\ Josef Havír \\ Ústav fyziky Země, PřF MU, Tvrdého 12, 60200 Brno; e-mail:josef.havir@ipe.muni.cz
}

Key words: seismic monitoring, СТВTO, nuclear explosions, discrimination

\begin{abstract}
Seismic station VRAC operated by IPE (Institute of Physics of the Earth) is part of the International Monitoring System CTBTO (Comprehensive Nuclear-Test-Ban Treaty Organization). This monitoring system is built for verification of the compliance with the Comprehensive Nuclear-Test-Ban Treaty. Station VRAC provided important registration of the nuclear explosions. Last explosions were carried out on the territory Democratic People's Republic of Korea (DPRK), latest North Korean nuclear test was conducted this year (12. 2. 2013). Station VRAC recorded signal of all North Korean nuclear explosions. Registrations by stations of International Monitoring System, including station VRAC, significantly contributed to improving of the discrimination techniques, mainly to improving the discrimination between natural earthquakes and explosions based on the analyses of Ms and mb magnitudes.
\end{abstract}

K významným politickým problémům současnosti patří problematika jaderných zbraní a s ní spojená problematika pokusných jaderných explozí. V roce 1996 byla předložena Valnému shromáždění OSN k podpisu Smlouva o úplném zákazu jaderných zkoušek (CTBT - Comprehensive Nuclear-Test-Ban Treaty). Do této chvíle podepsalo tuto smlouvu 183 států, včetně České republiky. Pro verifikaci dodržování Smlouvy CTBT je budován tzv. Mezinárodní monitorovací systém využívající čtyři různé monitorovací technologie (seismickou, infrazvukovou, radiometrickou a hydroakustickou). Významnou složkou je sít 170 seismických stanic.

Stanice VRAC (Vranov u Brna), provozovaná ÚFZ (Ústav fyziky Země, Masarykova Univerzita), je zařazena do seismické sítě Mezinárodního monitorovacího systému jako stanice s kódovým označením AS26. Stanice je v provozu od roku 1990 a během své činnosti se podílela na monitorování většího počtu pokus-
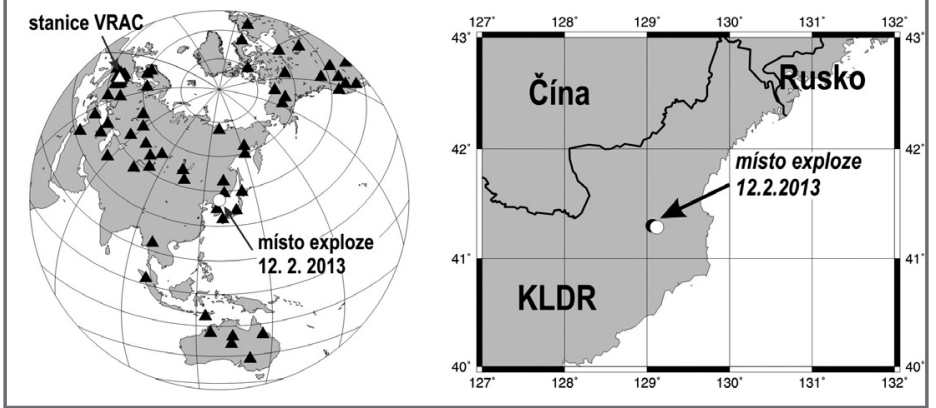

Obr. 1: Schematické mapy umístění epicentra severokorejské jaderné exploze z 12. 2. 2013 v globálním měřítku (vlevo) a v detailnějším výřezu (vpravo): kolečka - epicentrum jaderné exploze (bílé kolečko - lokace vypočítaná v ÚFZ, černé kolečko - lokace převzata z Mezinárodního datového centra CTBTO); trojúhelníky - pozice stanic využitých v ÚFZ k lokaci exploze.

Fig. 1: Schematic maps of epicentre position of the North Korean nuclear explosion from 12.2. 2013 in the global scale (left map) and in the regional scale (right map): circles - epicentre of the nuclear explosion (white circle - location calculated by IPE; black circle - location after International Data Centre CTBTO); triangles - stations used by IPE for location of nuclear explosion. ných jaderných explozí provedených v různých částech světa (Haviŕ et al. 1993). Kromě testů na území Číny (1995 až 1998, jaderná střelnice Lop Nor), Indie (1998, jaderná střelnice ve státě Dalbandin) a Pákistánu (1998, jaderná střelnice ve státě Pokaran) registrovala stanice VRAC kvalitní záznamy také v př́padě jaderných explozí provedených Francií na pacifických polygonech v souostroví Tuamotu (1990 až 1996, atoly Mururoa a Fangataufa). Zatím poslední pokusné jaderné exploze byly provedeny na území KLDR, přičemž nejnovější jaderný test proběhl v letošním roce (12. 2. 2013).

Jaderný test ze dne 12.2.2013 byl proveden na jaderném polygonu situovaném v severovýchodní části KLDR (obr. 1). Ve stejném regionu byly uskutečněny také před- chozí korejské jaderné exploze (9. 10. 2006 a 25. 5. 2009). Všechny tři zmíněné jaderné exploze byly registrovány stanicí VRAC (obr. 2). Jev z roku 2006 je nejslabší (hodnota magnituda mb počítaného $\mathrm{z}$ objemových vln byla 4.1) a signál exploze na záznamu stanice VRAC je výrazně ovlivněn šumem. Amplitudy signálů dalších dvou explozí již několikanásobně převyšují úroveň šumu a je tak možné vzájemně porovnat tvar vlnového záznamu. Z obrázku 2 je patrné, že tvar signálu letošního jevu je téměř identický s tvarem signálu exploze z roku 2009, oba vlnové záznamy se liší více méně jen rozdílnou amplitudou. Tato skutečnost ukazuje, že podmínky ve fokální zóně obou jevů byly podobné, včetně mechanismu exploze a fyzikálních vlastností 


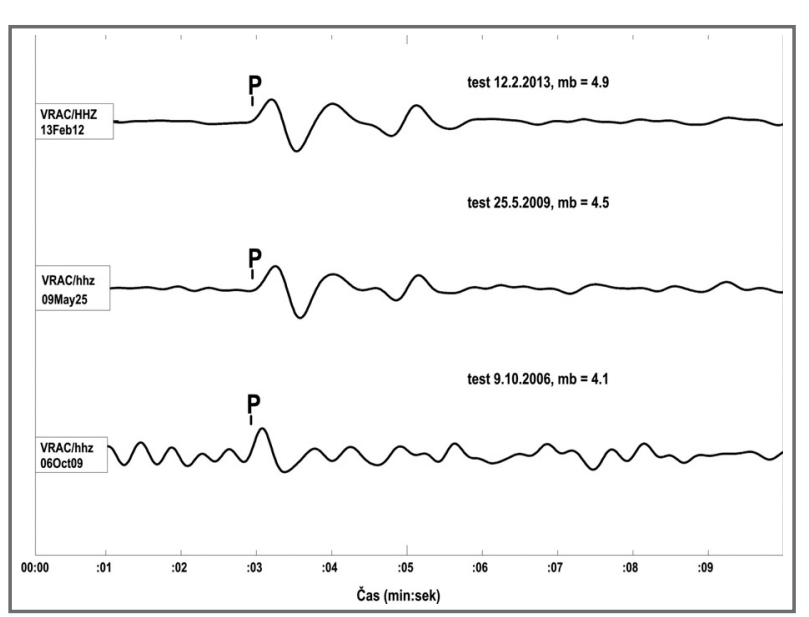

Obr. 2: Záznamy severokorejských jaderných explozí na stanici VRAC (vertikální složka, amplitudy mají nestejná měřítka).

Fig. 2: Waveforms of North Korean nuclear explosions registered by station VRAC (vertical component, amplitudes are in different scales).

hornin v okolí nálože. Lišila se však velikost nálože. Pro explozi z roku 2009 dosáhlo magnitudo mb spočtené z objemových vln hodnotu 4.5, zatímco hodnota magnituda mb letošní jaderné exploze byla 4.9 (údaje o hodnotách magnituda mb jsou převzaty $\mathrm{z}$ Mezinárodního datového centra CTBTO). Amplituda př́mé podélné vlny P odečtená na stanici VRAC byla v prípadě nové exploze z února 2013 trojnásobná oproti amplitudě signálu exploze z roku 2009 a více než o řád větší ve srovnání $s$ amplitudou exploze $\mathrm{z}$ roku 2006.

Pro účely verifikace dodržování Smlouvy CTBT je nutné seismický jev, který by mohl odpovídat jaderné explozi, nejen detekovat, ale také spolehlivě rozlišit záznam exploze a přirozeného zemětř̌esení. Jednou z významných diskriminačních metod pro rozlišení explozí a přirozených

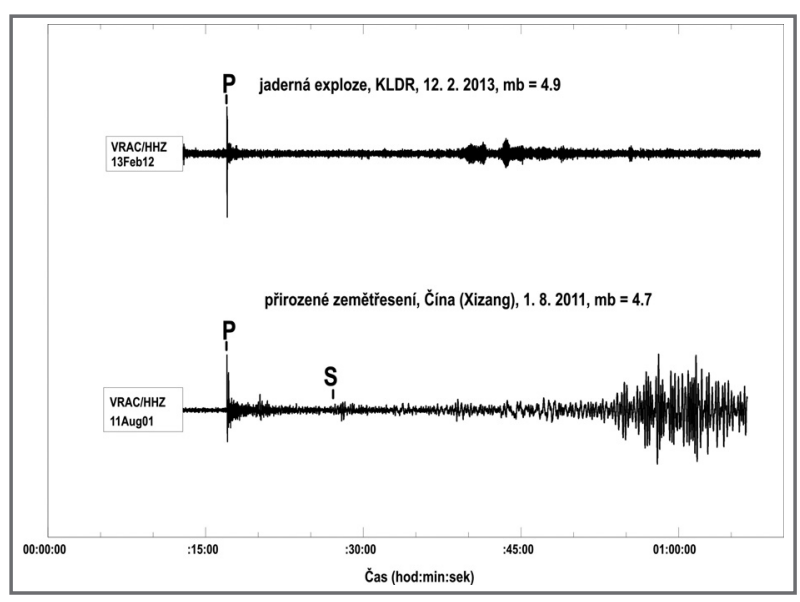

Obr. 3: Rozdíly v záznamu severokorejské jaderné exploze a přirozeného zemětřesení na stanici VRAC (vertikální složka, amplitudy mají nestejná měř́tka). Epicentra obou jevů jsou situovány ve srovnatelné epicentrální vzdálenosti od stanice VRAC. Fig. 3: Differences between waveforms of the North Korean nuclear explosion and of the natural earthquake (vertical component, amplitudes are in different scales). The epicentres of both events are situated in comparable epicentral distances from the station VRAC. zemětřesení je metoda založená na porovnání hodnot magnituda počítaného $\mathrm{z}$ objemových a $\mathrm{z}$ povrchových $\operatorname{vln}($ obr. 3).

Již v prvních desetiletích po provedení prvních jaderných explozí bylo při seismickém monitorování zjištěno, že povrchové vlny záznamů jaderných explozí na vzdálených stanicích mají řádově menší amplitudy ve srovnání s povrchovými vlnami mělkých přirozených zemètřesení (Basham - Horner 1973, Gupta et al. 1972). Tato skutečnost umožňuje jednoduchou a přitom dostatečně spolehlivou předběžnou diskriminaci mělkých seismických jevů pomocí lineárního vztahu (Weichert - Basham 1973):

$$
\mathrm{D}=\mathrm{A} \cdot \mathrm{Ms}+\mathrm{B}-\mathrm{mb}
$$

kde mb je magnitudo počítané z objemových vln, Ms je magnitudo počítané z povrchových vln, A a B jsou konstanty odvozené $\mathrm{z}$ korelace hodnot $\mathrm{mb}$ a Ms přirozených zemětřesení a ze zvolené úrovně pravděpodobnosti a $\mathrm{D}$ je hodnota tzv. „skóre“, která je porovnávána s limitními hodnotami. Je-li „skóre“ vyšší než limitní hodnota, pak je testovaný seismický jev se zvolenou pravděpodobností přirozeným zemètřesením.

Porovnání magnituda mb a Ms korejských jaderných explozí ukazuje, že „skóre“ těchto jevů dosahuje hodnot

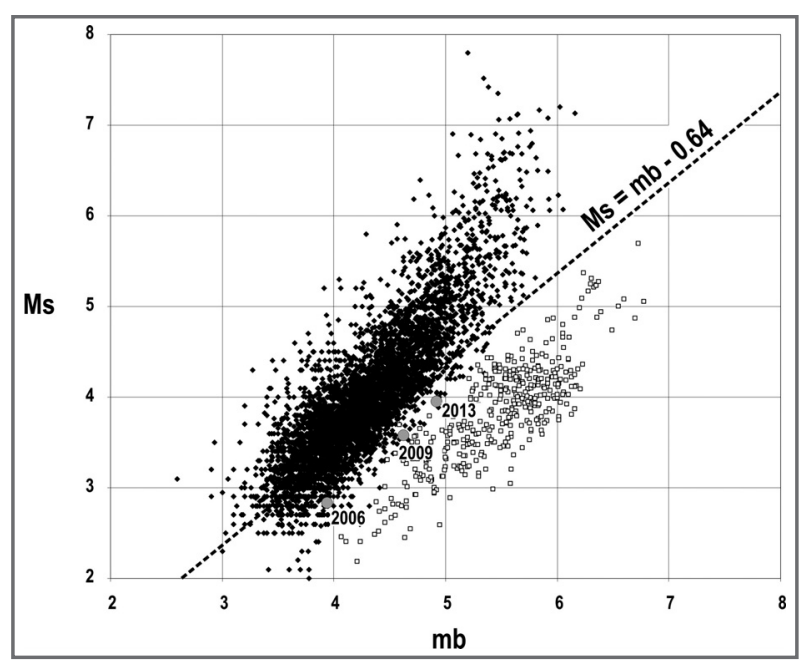

Obr. 4: Graf poměrů hodnot Ms a mb pro přirozená zemětřesení (černé kosočtverce) a jaderné exploze (bílé čtverce) s vyznačenou pozicí bodů odpovídajících severokorejským jaderným explozím (šedá kolečka). Přerušovaná čára znázorňuje kritérium pro rozlišení přirozených zemětřesení a jaderných explozí podle Selbyho et al. (2012). Údaje o hodnotách magnituda Ms a mb pro jaderné exploze jsou převzaty z práce Selby et al. (2012). Údaje pro přirozená zemětřesení jsou převzaty $\mathrm{z}$ tzv. REB-bulletinů Mezinárodního datového centra CTBTO z let 2002 až 2012.

Fig. 4: Ms:mb plot showing ratio of Ms and mb magnitudes for natural earthquakes (black diamonds) and for nuclear explosion (white squares) with indicated points representing the Norh Korean nuclear explosions (grey circles). Dashed line shows the criterion for discrimination between natural earthquakes and nuclear explosions after Selby et al. (2012). Values of Ms and $\mathrm{mb}$ of nuclear explosions are adopted after Selby et al. (2012). Values of Ms and $\mathrm{mb}$ of natural earthquakes are received from REB-bulletins of the International Data Centre for period from 2002 to 2012 
blízkých limitním hodnotám mezi přirozenými zemětřeseními a jadernými explozemi (obr. 4). Na základě analýz korejských jaderných odpalů bylo nutné upravit původní předběžné kritérium testované v Mezinárodním datovém centru CTBTO (kritérium podle Fiska et al. 2002), protože zvolené limitní hodnoty se ukázaly být nedostatečně spolehlivé pro vlnové záznamy explozí odpovídající korejským jaderným testům (Selby et al. 2012). Od loňského roku je proto $\mathrm{v}$ Mezinárodním datovém centru aplikováno nové provizorní testovací kritérium, vycházející ze vztahu empiricky odvozeného Selbym et al. (2012):

$$
\mathrm{Ms}=\mathrm{mb}-0.64
$$

Toto kritérium umožňuje testovat mělké seismické jevy tak, aby bylo možné $\mathrm{z}$ dalších testů vyloučit co největší množství přirozených zemětřesení a aby přitom současně nedocházelo k vyloučení žádného záznamu jaderné exploze.

Monitorování jaderných explozí provedených na území KLDR tak významně přispělo $\mathrm{k}$ analýze a vylepšení diskriminačních technik pro rozlišení seismických záznamů explozí a přirozených zemětřesení. Zásadní význam přitom měly záznamy na stanicích Mezinárodního monitorovacího systému CTBTO, mezi jinými také na seismické stanici VRAC.

\section{Poděkování}

Př́spěvek vznikl s finanční podporou projektů CzechGeo/ EPOS program č. LM2010008 a ESF/MŠMT projekt CZ.1.07/2.3.00/20.0052 „Výzkumný tým pro ukládání radioaktivních odpadi̊ a jadernou bezpečnost".

\section{Literatura}

Basham, P. W. - Horner, R. B. (1973): Seismic magnitudes of underground nuclear explosions. - Bulletin of the Seismological Society of America, 63, 105-131.

Fisk, M. D. - Jepsen, D. - Murphy, J. R. (2002): Experimental Seismic Event-screening Criteria at the Prototype International Data Center. - Pure and Applied Geophysics, 159, 865-888.

Gupta, H. K. - Sitaram, M. V. D. - Narain, H. (1972): Surface-wave and body-wave magnitudes of some sino-soviet nuclear explosions and earthquakes. - Bulletin of the Seismological Society of America, 62, 2, 509-517.

Havíŕ, J. - Švancara, J. - Otruba, J. (2003): Úloha a využití nově certifikované seismologické stanice VRAC v rámci Mezinárodního monitorovacího systému CTBTO. - Sborník vědeckých prací VŠB-TU Ostrava, řada stavební, 3, 2, 77-84.

Selby, N. D. - Marshall, P. D. - Bowers, D. (2012): mb: Ms Event Screening Revisited. - Bulletin of the Seismological Society of America, 102, 1, 88-97.

Weichert, D. H. - Basham, P. W. (1973): Deterrence and false alarms in seismic discrimination. - Bulletin of the Seismological Society of America, 63, 1119-1132. 